\title{
Lūcija Strauta
}

\section{Sapnis par kosmosa}

bagātībām - vai kosmosa

resursu ieguve ir likumīga?

A dream about space resources is space mining legal?

\begin{abstract}
The paper assesses whether the national legal framework of the United States, Luxembourg and the United Arab Emirates, which stipulates that space resources can be privately owned, and legalizes the acquisition of space resources for commercial purposes, complies with international space law.

The article analyses the scope of space use delineated by the 1967 Treaty on Principles Governing the Activities of States in the Exploration and Use of Outer Space, including the Moon and Other Celestial Bodies and 1979 Agreement Governing the Activities of States on the Moon and Other Celestial Bodies, as well as the subsequent national practices after the entry into force of these agreements, national space law, national policies and public statements. The aim of the analysis is to determine whether international space law contains a prohibition of the extraction and commercial exploitation of space resources. The study evaluates national comprehensions of the space law content with regard to the freedom to use space. It yields a conclusion that there is no absolute ban on the commercial exploitation of space resources under international space law.

Keywords: extraction of space resources, commercial use of space, private ownership of space, Treaty on Principles Governing the Activities of States in the Exploration and Use of Outer Space, including the Moon and Other Celestial Bodies, freedom of space use.
\end{abstract}




\section{levads}

Palielinoties privāto kompāniju īpatsvaram kosmosa nozarē, aktualizējas jautājums par skaidra tiesiskā regulējuma trūkumu [Christian, Soucek 2011: 491-725]. Izmantojot starptautisko līgumu plašo tvērumu, 2015. gadā ASV, neilgi pēc tam arī Luksemburga un Apvienotie Arābu Emirāti (turpmāk - AAE), pieñēma nacionālos likumus, kas regulē privātpersonu komerciālo darbību kosmosā, t. sk. nosakot, ka kosmosa resursi var būt privātīpašums. Tomēr tiesību zinātnieki pauž bažas, ka šāda vienpusēja rīcība ir pretrunā starptautiskajiem līgumiem [Mallick, Rajagopalan 2019: 16].

Raksta mērkis ir noskaidrot starptautisko kosmosa tiesību saturu attiecībā uz kosmosa resursu ieguvi: vai starptautiskajās kosmosa tiesībās pastāv absolūts aizliegums komerciāli izmantot kosmosu un vai minētie nacionālie likumi atbilst starptautiskajām kosmosa tiesībām.

Raksta pirmajā nodalıā tiks aplūkots ASV, Luksemburgas un AAE nacionālā tiesiskā regulējuma saturs, lai turpmākajās nodaḷās varētu vērtēt to atbilstību starptautiskajām tiesībām. Otrajā nodalāa tiks pētīti starptautisko kosmosa tiesību avoti. Trešajā nodaḷā tiks analizēta valstu turpmākā prakse pēc 1967. gada "Līguma par valstu darbības principiem kosmosa, tostarp Mēness un citu debess ḳermeṇu, izpētē un izmantošanā” (turpmāk - Kosmosa līgums) spēkā stāšanās, 1979. gada "Līguma par valstu darbību uz Mēness un citiem debess kermeṇiem" (turpmāk - Mēness līgums) vispārsaistošais raksturs, kā arī izvērtētas paražu normas. Papildus tiks izvērtēta citu valstu pozīcija attiecībā uz Kosmosa līguma interpretāciju, kas atspoguḷota valstu nacionālajos likumos un publiskajos paziṇojumos.

\section{Kosmosa resursu ieguves nacionālais tiesiskais regulējums}

2015. gada novembrī tika izsludināts ASV komerciālo kosmosa lidojumu konkurētspējas likums, kura 51303. paragrāfs piešḳir tiesības ASV pilsoniem iegūt asteroīdu un kosmosa resursus. Neilgi pēc tam Luksemburga pieṇēma 2017. gada 20. jūlija kosmosa izpētes un resursu izmantošanas likumu, bet 2019. gadā AAE spēkā stājās federālais likums Nr. 12 
"Par kosmosa sektora regulējumu”. Šāda tiesiskā regulējama tapšana saistīta ar privāto kosmosa operatoru strauju attīstību [Cumbers 2020].

Minētie nacionālie likumi ir konceptuāli līdzīgi, un tajos ir ietverti vienādi principi un izpratne par kosmosa resursu statusu. Pirmkārt, tajos ietverta norāde, ka kosmoss ir izmantojams saskaṇā ar valsts likumiem, t. sk. ar valsts starptautiskajām saistībām. Vienlaikus likumos ietverta norāde vai no likuma izriet, ka tie nav vērsti uz kosmosa un debess ḳermen,u apropriāciju (ASV likuma 403. pants; Luksemburgas likuma 2. pants; AAE likuma 2. pants). Otrkārt, nacionālajos likumos uzsvērta kosmosa izmantošanas brīvība, interpretējot to tādējādi, ka ikvienam ir tiesības izmantot kosmosu jebkādiem mērḳiem, ja vien tas tieši nav aizliegts Kosmosa līgumā (kā militāri mērḳi vai debess ḳermeṇa teritorijas okupācija). Papildus tam likumos nostiprināts uzskats, ka debess kermenis un tā resursi nav viens un tas pats un ka apropriācijas aizliegums attiecas tikai uz debess ḳermeni kā tādu un tā teritoriju, taču neattiecas uz resursiem. Attiecībā uz īpašumtiesību rašanos visos likumos ietverts princips, ka tās izveidojas ar resursu iegūšanas brīdi un ka nav iespējams īpašumtiesības nostiprināt uz vēl neiegūtiem kosmosa resursiem. Vienlaikus likumos nostiprināts princips, ka resursu īpašnieks ir tas, kas veicis resursu ieguvi (ASV likuma 513030 §; Luksemburgas likuma 1. pants; AAE likuma 18. pants).

\section{Kosmosa resursu izmantošanu regulējošie starptautiskie līgumi}

No ANO izstrādātajiem kosmosa tiesību līgumiem uz resursu komerciālu ieguvi ir attiecināms Kosmosa līgums un Mēness līgums.

Kosmosa līgums tiek pielīdzināts kosmosa tiesību konstitūcijai un uzskatīts par kosmosa tiesību pamatlīgumu [Mallick, Rajagopalan 2019: 10]. Kosmosa līgumu ir ratificējusi lielākā daḷa pasaules valstu - 109 (parakstījušas - 23) [UNOOSA 2019], t. sk. visas kosmosa industriju vadošās valstis. Kosmosa līguma pirmais pants noteic, ka kosmoss ir res communis [Brownlie 2008: 35] un visas valstis var izmantot kosmosu brīvi, savukārt otrais pants noteic, ka "kosmoss, tostarp Mēness un citi debess ḳermen,i, nav pakḷaujami valstiskai apropriācijai, pasludinot suverenitāti, izmantojot vai okupējot to, vai jebkādā citā veidā”. 
Diskusijas par Kosmosa līguma regulējuma saturu aizsākās jau uzreiz pēc tā spēkā stāšanās. Kosmosa līgumā ietverti vairāki jēdzieni, kuru saturs pašā līgumā nav skaidrots, tādē| to interpretācija radījusi tiesību zinātnieku diskusijas. Viṇi nav vienisprātis, vai jēdziens "brīvi izmantojams" ietver [Report of the Legal Subcommittee on its fifty-seventh session 2018: 238] vai neietver [Lits, Stepanov 2017: 237] komerciālu izmantošanu, vai resursu ieguve veido valstisku apropriāciju [Lits, Stepanov 2017: 237] vai neveido [Coffey 2009: 125-126]. Būtiskākie Kosmosa līguma jēdzieni, kuru satura noskaidrošana attiecībā uz kosmosa resursu ieguvi ir svarīga, ir "visu valstu labā”, "visas cilvēces tiesība”, "brīvi izmantojams”, "izmantojams tikai miermîlīgiem mērkiem” un "valstiska apropriācija”.

Izvērtējot Kosmosa līguma satura krasi atškirīgās interpretācijas, jāsecina: kaut gan līgums nodibina kosmosa resursu izmantošanas vadīnijas, tā regulējums attiecībā uz resursu ieguvi ir plašs, nepietiekams un neviennozīmīgs. Tādējādi nav iespējams rast skaidru atbildi, vai kosmosa resursus drīkst iegūt privātas kompānijas komerciāliem mērḳiem vai tomēr ne.

Mēness līgums ir pieṇemts kā pēdējais no pieciem ANO līgumiem. Minētajā līgumā iestrādātais regulējums ir attiecināts uz kosmosa un tā resursu izmantošanu, sašaurinot Kosmosa līguma saturu [UNOOSA, b. g.]. Mēness līguma 4. pantā ir nostiprināts Mēness brīvas izmantošanas princips un visas cilvēces tiesība to izmantot, bet 11. pantā ir ietverts expressis verbis aizliegums iegūt īpašumtiesības pār kosmosa resursiem.

Tomēr Mēness līgums nav kategorisks: 11. panta piektajā daḷā līguma izstrādātāji ir paredzējuši, ka nākotnē, attīstoties tehnoloǵijām, starptautiskā sabiedrība tomēr varētu izmantot debess ḳermeṇu resursus. Tādējādi līguma mērḳis ir nevis aizliegt kosmosa resursu ieguvi pavisam, bet līdz brīdim, kad būs nepieciešamība to legalizēt.

Atšḳirībā no Kosmosa līguma, Mēness līgums netiek uzskatīts par kosmosa tiesību konstitūciju - līgumu ir ratificējušas tikai 18 valstis (parakstījušas 4) [UNOOSA 2019], no kurām vairumam nav attīstītas kosmosa nozares un kuras nepiedalās kosmosa lidojumos un izpētē. Pastāv uzskats: kaut gan Mēness līgums faktiski pasaules valstīm nav saistošs kā līgums, tā saturs uzskatāms par starptautiskajām kosmosa paražu tiesībām [Mallick, Rajagopalan 2019: 15]. Tomēr Mēness līguma saturs nav 
saistošs, vērtējot kosmosa resursu ieguvi [Wasser, Jobes 2008: 43] (tas mainītos, ja to ratificētu kosmosa lielvalstis [Builder 2009: 259]). Mēness līgums nevar veidot paražu tiesības, jo nav konstatējama vispārizplatīta un atzīta vienveidīga valstu prakse, gluži otrādi - valstu rīcība norāda uz pilnīgi pretēju praksi [Gangale 2009: 352] (skat. 3. nod.). Tā kā Mēness līgums nav kosmosa tiesību paražu normu kodifikācija, tajā ietvertais regulējums nav saistošs valstīm, kas nav to ratificējušas. Tāpēc par ASV, Luksemburgai un AAE saistošiem tiesību avotiem atzīstams Kosmosa līgums un paražu tiesību normas, kuras veidojušās kopš 20. gs. vidus.

\section{Starptautiskās paražu normas un valstu prakse}

Starptautisko līgumu dalībvalstīm ir tiesības līgumu interpretēt, un vērā ṇemama ir arī valstu turpmākā prakse, kā tās līguma normas piemēro [Vīnes konvencija 1964]. Kosmosa paražu normas sāka veidoties 20. gs. vidū, kad aizsākās lidojumi kosmosā un izpētes misijas, kuru laikā tika iegūti dažādi paraugi. Kopš 1967. gada sāka nostiprināties atradēja (angl. finders, keepers) princips [Gangale, Dudley-Rowley 2006: 1].

Atradēja princips nozīmē to, ka tas, kurš resursus atrod un iegūst, var tos paturēt kā savu īpašumu. Šis princips, attiecināts uz kosmosa resursiem, atbilst Kosmosa līgumam, jo neviens par savu īpašumu nevar pasludināt in situ kosmosa resursus, bet, tiklīdz minerāls vai iezis ir iegūts, tas kḷust par ieguvēja īpašumu [Gangale, Dudley-Rowley 2006: 4-5].

Šāda paraža ir iedibinājusies praksē: ASV, Krievija un Japāna ir ieguvušas valdījumā un izmantojušas kosmosa resursus [Smith 2015: 8]. Uzskats, ka īpašumtiesības uz kosmosā iegūtiem resursiem pieder ieguvējam, nostiprinātas arī ASV tiesu praksē [Sarnacki 2014: 138]. Kā norāda tiesību zinātnieki, ASV un PSRS īpašumtiesības uz savāktajiem kosmosa resursiem nekad nav apstrīdētas. Tādējādi vairākās desmitgadēs šāds atradēja princips izveidojies kā paražu norma [Gangale 2006: 1-2].

Turklāt kosmosā iegūti resursi ir bijuši komerciāla darījuma priekšmets. 1993. gadā tika pārdoti PSRS 1970. gada "Luna Programme" ietvaros iegūtie Mēness akmeṇi kādai privātpersonai "Sotheby" izsolē par 422500 ASV dolāriem [Reed 2002]. 2011. gada NASA ziṇojumā norādīts, ka "Apollo" programmas ietvaros iegūtie Mēness paraugi ir ASV valdības 
īpašums [Gangale 2006: 10]. Neviena Kosmosa līguma dalībvalsts šādas darbības nav uzskatījusi par līguma pārkāpumu un nav iebildusi pret ierasto praksi [Sachdeva 2014: 8].

Atradēja princips, kas iesakṇojies kosmosa paražu tiesībās, ir ietverts gan ASV, gan Luksemburgas, gan AAE likumā, šo principu piemērojot arī privātpersonu darbībām kosmosā [Mallick, Rajagopalan 2019: 10].

Vērtējot pasaules valstu kosmosa politiku (Indija, Krievija, K̦īna, Japāna, Kazahstāna, papildus Eiropas Kosmosa aǵentūra), jāsecina, ka privātu kompāniju klātbūtne un komerciāla izmantošana kosmosā ir veidojusies vairāku desmitgažu laikā un joprojām ir aktuāla.

Tādējādi, apvienojot pastāvošo valstu praksi attiecībā uz abiem jautājumiem, jāsecina, ka privāto kompāniju veikta kosmosa resursu ieguve komerciālā nolūkā atbilst valstu izpratnei par Kosmosa līgumā ietvertajiem tiesību principiem. Pret ASV, Luksemburgas un AAE likumiem starptautiskā sabiedrība nav noraidoša, daḷa tos vērtē atturīgi, norādot uz problēmu, ka šādas darbības nav regulētas vienoti. Arī vairums kosmosa tiesību zinātnieku sliecas par labu tādai Kosmosa līguma interpretācijai, kas pieḷauj privātu personu īpašumtiesības uz kosmosa resursiem [Reaven 2016: 28]. Tomēr tas, vai šāda rīcība arī turpmāk atbildīs starptautiskajām kosmosa tiesībām, rādīs turpmākā tiesību attīstība - jaunu, specializētu līgumu izstrāde vai starptautisku paražu normu rašanās [Gorove 1969: 351].

\section{Secinājumi}

Pētījuma rezultātā autore izvirza šādas tēzes:

Kosmosa līguma regulējums ir pārāk abstrakts, un kosmosa izmantošanas noteikumus noteiks prakse un gan tās paražu normas, kas veidojušās kopš pirmajām kosmosa izpētes misijām, gan tās, kas veidojas no mūsdienu precedentiem, ja vien netiks pien,emts speciāls un visām valstīm saistošs tiesiskais regulējums.

Par visai starptautiskajai sabiedrībai saistošu tiesību avotu nav atzīstams Mēness līgums, jo to ratificējušas vien 18 valstis, kas neveic aktīvas darbības kosmosā. Tādējādi tas neierobežo valstu tiesības, kas nav dalībnieces, legalizēt kosmosa resursu ieguvi komerciāliem mērḳiem. 
Starptautisko kosmosa tiesību mērḳis nekad nav bijis absolūts kosmosa resursu ekspluatēšanas un to komerciālas izmantošanas aizliegums. Mēness līgums paredz pagaidu aizliegumu iegūt īpašumtiesības uz debess k̦ermeñu resursiem, kamēr rastos vajadzība aizliegumu atcelt un nodibināt starptautisku regulējošu režīmu.

Kosmosa komercializācija veidojusies pēdējo desmitgažu laikā, un mūsdienās valstis to uzskata par vienu no svarīgākajiem ekonomikas un labklājības veicināšanas stūrakmeṇiem. Tulkojot Kosmosa līguma saturu pēc valstu turpmākās prakses, secināms, ka kosmosa komerciāla izmantošana un kosmosa resursu ieguve valsts vajadzībām saskan ar valstu izpratni par miermīlīgas kosmosa izmantošanas principa saturu.

Kopš sākotnējām kosmosa izpētes misijām veidojusies regulāra un vienveidīga prakse, kas paredz, ka tas, kas resursus ieguvis valdījumā, var tos paturēt un ir to īpašnieks. Valstu īpašumtiesības uz savāktajiem kosmosa resursiem nekad nav tikušas apstrīdētas, un atsevišḳi precedenti nostiprina īpašnieka tiesības gan aizsargāt, gan pārdot īpašumā esošos kosmosa resursus. Tādējādi starptautiskajās tiesībās ir izveidojusies paražu norma, kas tiek dēvēta par atradēja (finders, keepers) principu. Līdz ar to kosmosa resursu ieguve un to komerciāla izmantošana atbilst starptautisko kosmosa tiesību paražu normām.

Nacionālie likumi, kas legalizē privātpersonu kosmosa resursu ieguvi komerciāliem mērkiiem, ir balstīti uz visu valstu tiesībām brīvi izmantot kosmosu, savukārt īpašumtiesību rašanās pamatā ir atradēja princips. Līdz ar to nacionālie likumi nepārkāpj kosmosa tiesības, ja vien resursu ieguves process nekaitē vai pilnībā neatṇem tiesības izmantot kosmosu citām valstīm.

"Līguma par valstu darbības principiem kosmosa, tostarp Mēness un citu debess ḳermeṇu, izpētē un izmantošanā” pirmajā pantā ietvertā kosmosa izmantošanas brīvība it īpaši jāskata kopsakarā ar otrajā pantā ietverto izmantošanas brīvības ierobežojumu. Tomēr valstu prakse un paražu normas ḷauj secināt, ka kosmosa resursu ieguve un ekspluatēšana ietilpst terminā "izmantot" un ir dala no valstu kosmosu izmantošanas brīvības. 


\section{Izmantotā literatūra}

1. About Agreement Governing the Activities of States on the Moon and Other Celestial Bodies. Pieejams: https://www.unoosa.org/oosa/en/ourwork/ spacelaw/treaties/intromoon agreement.html (skatīts 18.04.2020.)

2. Brownlie, I. (2008). Principles of Public International Law. 7th edition. United States: Oxford University Press Inc.

3. Builder, R. B. (2009). A Legal Regime for the Mining of Helium-3 on the Moon: U. S. Policy Options. In: Fordham International Law Journal, Vol. 33, Iss. 2.

4. China's Space Activities in 2016. Pieejams: http://www.scio.gov.cn/ zfbps/32832/Document/1537024/1537024.htm (skatīts 18.04.2020.)

5. Christian Brünner, C., Soucek, A. (2011). Outer Space in Society, Politics and Law (Studies in Space Policy). Wien: Springer-Verlag Wien.

6. Coffey, S. (2009). Establishing a Legal Framework for Property Rights to Natural Resources in Outer Space Resources in Outer Space. In: Case Western Reserve Journal of International Law, Vol. 41, Iss. 1.

7. Cumbers J. The new space race: meet the investors building a new space settlement industry. Publicēts: 18.02.2020. Pieejams: https://www.forbes. com/sites/johncumbers/2020/02/18/the-new-space-race-meet-the-investors-building-a-new-space-settlement-industry/\#39300fed6b58 (skatīts 18.04.2020.)

8. Gangale, T., Dudley-Rowley, M. (2005). To Build Bifrost: Developing Space Property Rights and Infrastructure.

9. Gangale, T. (2009). The Development of Outer Space: Sovereignty and Property Rights in International Space Law. California: ABC-CLIO Inc.

10. Gorove S. (1969). Interpreting Article II of the Outer Space Treaty. In: Fordham Law Review, Vol. 37, Iss. 3.

11. Japan's Basic Plan on Space Policy. (2013). Pieejams: https://www8.cao.go.jp/ space/plan/plan-eng.pdf (skatīts 18.04.2020.)

12. Law of the Russian Federation "About space activity" [Krievijas Federācijas likums "Par darbībām kosmosā”]. Pieejams: https://www.unoosa.org/oosa/en/ ourwork/spacelaw/nationalspacelaw/russian_federation/decree_5663-1_E. html (skatīts 18.04.2020.)

13. Law of the Republic of Kazakhstan on Space Activities 6 January 2012 No. 528-IV [Kazahstānas Republikas likums "Par darbībām kosmosā”]. 
Pieejams: https://www.unoosa.org/documents/pdf/spacelaw/national/kazakhstan/528-IV_2012-01-06E.pdf (skatīts 18.04.2020.)

14. Līgums par valstu darbības principiem kosmosa, tostarp Mēness un citu debess k̦ermen,u, izpētē un izmantošanā. Parakstīts Londonā, Maskavā un Vašingtonā 27.01.1967. (11.09.2020. red.)

15. Līgums par valstu darbību uz Mēness un citiem debess ḳermeṇiem. Parakstīts N̦ujorkā 18.12.1979. (11.09.2020. red.)

16. Lits, M., Stepanov, S., Tikhomirova, A. (2017). International space law. In: BRICS Law Journal, pp. 135-155.

17. Loi du 20 juillet 2017 sur l'exploration et l'utilisation des ressources de l'espace [2017. gada 20. jūlija kosmosa izpētes un resursu izmantošanas likums]. Pieejams: http://data.legilux.public.lu/file/eli-etat-leg-loi-2017-0720-a674-jo-fr-pdf.pdf (skatīts 18.04.2020.)

18. Mallick, S., Rajagopalan, R. P. (2019). If space is "the province of mankind", who owns its resources? In: Observer Research Foundation Occasional Paper, No. 182.

19. Mr. Smith of Texas, from the Committee on Science, Space, and Technology, report together with minority views on Space Resources Exploration and Utilization Act of 2015. Pieejams: https://www.congress.gov/114/crpt/hrpt153/ CRPT-114hrpt153.pdf (skatīts 11.09.2020.)

20. Reaven, E. (2016). The United States Commercial Space Launch Competitiveness Act: The Creation of Private Space Property Rights and the Omission of the Right to Freedom From Harmful Interference. In: The Washington University Law Review, Vol. 94, Iss. 1.

21. Reed, C. (2002). Moon rocks for sale! Nr. 09/2002. Pieejams: https://web. archive.org/web/20030518104456/http://www.geotimes.org/sept02/NN_ moon.html [skatīts 18.04.2020.]

22. Report of the Legal Subcommittee on its fifty-seventh session, held in Vienna from 9 to 20 April 2018. Pieejams: https://www.unoosa.org/oosa/en/ ourwork/copuos/2018/index.html (skatīts 11.09.2020.)

23. Status of International Agreements relating to activities in outer space as at 1 January 2019. Pieejams: https://www.unoosa.org/documents/pdf/spacelaw/ treatystatus/AC105_C2_2019_CRP03E.pdf (skatīts 11.09.2020.)

24. The United Arab Emirates Federal Law No. (12) of 2019 "On the regulation of the space sector" [AAE federālais likums Nr. 12 "Par kosmosa sektora 
regulējumu"]. Pieejams: https://www.moj.gov.ae/assets/2020/Federal\%20 Law\%20No\%2012\%20of\%202019\%20on\%20THE\%20REGULATION\%20 OF\%20THE\%2OSPACE\%2OSECTOR.pdf.aspx (skatīts 18.04.2020.)

25. UAE national space policy. Pieejams: https://space.gov.ae/Documents/ PublicationPDFFiles/UAE_National_Space_Policy_English.pdf (skatīts 18.04.2020.)

26. U.S. Commercial Space Launch Competitiveness Act [ASV komerciālo kosmosa lidojumu konkurētspējas likums]. Pieejams: https://www.congress.gov/114/ plaws/publ90/PLAW-114publ90.pdf (skatīts 18.04.2020.)

27. Vīnes konvencija par starptautisko līgumu tiesībām. Parakstīta Vīnē 24.04.1964. (11.09.2020. red.). Pieejams: https://www.unoosa.org/documents/pdf/spacelaw/national/kazakhstan/528-IV_2012-01-06E.pdf (skatīts 18.04.2020.)

28. Wasser, A., Jobes, D. (2008). Space Settlements, Property Rights, and International Law: Could a Lunar Settlement Claim the Lunar Real Estate It Needs to Survive. In: Journal of Air Law and Commerce, Vol. 73, Iss. 1. 